\title{
The role of lipopolysaccharide in complement-killing of Aeromonas hydrophila strains of serotype $0: 34$
}

\author{
Susana Merino, Silvia Camprubí and Juan M. Tomás* \\ Departamento de Microbiologia, Universidad de Barcelona. Diagonal 645, 08071 Barcelona, Spain
}

(Received 10 August 1990; revised 27 January 1991; accepted 25 March 1991)

\begin{abstract}
The role of lipopolysaccharide (LPS) in the susceptibility of Aeromonas hydrophila strains of serotype 0:34 to non-immune human serum was investigated using isogenic mutants (serum-sensitive), previously obtained on the basis of phage resistance, and characterized for their surface components. The classical complement pathway was found to be principally involved in the serum-killing of these sensitive strains. LPS preparations from serumresistant or serum-sensitive strains, or purified core oligosaccharides (low-molecular-mass LPS) inactivated both bactericidal and complement activity of whole serum, while the $\mathrm{O}$-antigen molecules (high-molecular-mass LPS) did not. The results indicate that LPS core oligosaccharide composition contributes to complement resistance of $A$. hydrophila strains from serotype 0:34 with moderate virulence.
\end{abstract}

\section{Introduction}

The bactericidal effect of non-immune serum is important in immediate host defence against bacterial infections. This phenomenon has been widely studied (Morrison \& Kline, 1977; Nelson \& Roantree, 1967; Taylor, 1983, 1988), and is known to be complementmediated (Roantree \& Pappas, 1960). Although serum resistance in Gram-negative bacteria can be multifactorial in vivo, the outer membrane is predominantly important since it is usually the most peripheral component of the bacterial cell envelope. Outer membrane components such as lipopolysaccharide (LPS) (Munn et al., 1982; Mushel \& Larsen, 1970; Nelson \& Roantree, 1967), and proteins (Guyman et al., 1978; Hildebrant et al., 1978; Moll et al., 1980), as well as other components of the bacterial cell surface, such as capsular polysaccharides, have been implicated in resistance to the bactericidal activity of serum (Glynn \& Howard, 1970; Rice \& Kasper, 1977; Sutton et al., 1982).

Complement activation by Gram-negative bacteria can occur via the classical complement pathway (CCP) or the alternative complement pathway (ACP). The CCP can be activated by the interaction of antibody with bacterial surface antigens or sometimes more directly by

Abbreviations: CCP, classical complement pathway; $\mathrm{ACP}$, alternative complement pathway; HMM-LPS, high-molecular-mass lipopolysaccharide; LMM-LPS, low-molecular-mass lipopolysaccharide; NHS, non-immune human serum; KDO, 2-keto-3-deoxyoctulosonic acid (3-deoxy-D-manno-octulosonic acid). the lipid A moiety of LPS (Morrison \& Kline, 1977). The ACP can normally be activated by bacterial polysaccharides independently of antibody (Quinn et al., 1977).

Aeromonas hydrophila is both an opportunistic and a primary pathogen of a variety of aquatic and terrestrial animals, including humans (Howard \& Buckley, 1985). The clinical manifestation of $A$. hydrophila infection ranges from gastroenteritis to soft tissue infections, septicaemia, and meningitis (Freij, 1984; Ljungh \& Wadstrom, 1983). Surface characteristics, such as the presence of an S-layer or the type of LPS, permit classification of $A$. hydrophila into different categories on the basis of their virulence (Janda et al., 1985; Dooley et al., 1985). We recently described a group of $A$. hydrophila strains belonging to serotype $0: 34$ with heterogeneous O-polysaccharide chains in their LPS and without an Slayer, previously reported to be moderate in their virulence for fish and mice (Lallier et al., 1984; Merino \& Tomás, 1988; Merino et al., 1989). Also, serotype O 34 has been recently reported as one of the most frequently encountered among mesophilic Aeromonas species (Thomas et al., 1990).

In the present study, we investigated the pathway of complement activation by $A$. hydrophila strains of serogroup $O: 34$, and the role of LPS in the susceptibility of these strains to the bactericidal activity of nonimmune serum, by using phage-resistant mutants (serum-sensitive) against bacteriophages 18 and PM2, whose bacterial receptor is the LPS-core region (Merino et al., 1990a, b). Further, we examined the role 
of high-molecular-mass LPS (HMM-LPS), containing O-antigen repeating units, and low-molecular-mass LPS (LMM-LPS), devoid of $\mathrm{O}$-antigen polysaccharide, in this process.

\section{Methods}

Bacterial strains. The strains used are listed in Table 1. Cultures were maintained and grown as previously described (Merino et al., 1989).

Bacterial survival in fresh non-immune serum. The survival of exponential-phase bacteria in non-immune human serum (NHS) was measured at $20^{\circ} \mathrm{C}$ and $37^{\circ} \mathrm{C}$ as previously described (Tomás et al., 1986). Controls consisting of bacteria in PBS (containing $0.15 \mathrm{M}$ sodium chloride and $0.15 \mathrm{M}$-sodium phosphate, $\mathrm{pH} 7.2$ ) showed no significant changes in viable counts over the incubation period. We used heat-inactivated NHS $\left(56^{\circ} \mathrm{C}\right.$ for $\left.30 \mathrm{~min}\right)$ as an additional control. Serum was usually used on the day of the collection or stored at $-80^{\circ} \mathrm{C}$, and these sera were unable to agglutinate $A$. hydrophila strains.

Serum-resistant mutants were obtained as survivors after treatment with NHS for $3 \mathrm{~h}$. After $36 \mathrm{~h}$ of incubation at $20^{\circ} \mathrm{C}$, colonies of serumresistant mutants were picked, purified by streaking, and retested with NHS to confirm resistance.

Treatment of serum. CCP activity in whole serum was selectively inhibited by chelation with $20 \mathrm{~mm}$-EGTA plus $2 \mathrm{~mm}-\mathrm{MgCl}_{2}$ as previously described (Fine et al., 1972). ACP activity in serum was selectively inhibited with inulin $\left(2 \mathrm{mg} \mathrm{ml}^{-1}\right)$ by the method of Gotze \& Muller-Eberhard (1971), or by heating at $50^{\circ} \mathrm{C}$ for $20 \mathrm{~min}$ in order to inactivate factor B, which is required for ACP activity (Eidinger $e t$ al., 1977). After each serum treatment the decrease in complement activity was assayed by the method of Morrison \& Kline (1977), as modified in a microtitre assay by Vukajlovich (1986). Both pathways were inhibited by treatment of serum with $20 \mathrm{~mm}$-EDTA or by heating at $56^{\circ} \mathrm{C}$ for $30 \mathrm{~min}$. EGTA, EDTA, and inulin, at the concentrations mentioned above, had no effect on the survival of $A$. hydrophila strains in PBS for up to $3 \mathrm{~h}$ of incubation.
LPS isolation and subfractionation. LPS from $A$. hydrophila strains was purified by the method of Westphal \& Jann (1965) with the modifications of Osborn (1966). Lyophilized LPS was solubilized at a final concentration of $7.5 \mathrm{mg} \mathrm{ml}^{-1}$ in buffer containing $3 \%(\mathrm{w} / \mathrm{v})$ sodium deoxycholate and applied to Sephacryl S-300 (Pharmacia) column as previously described (Ciurana \& Tomás, 1987). Fractions were analysed by SDS-PAGE or dialysed extensively against distilled water, first at room temperature and then at $4{ }^{\circ} \mathrm{C}$, before chemical analyses or serum inhibition studies were performed.

Electrophoretic techniques. SDS-PAGE was done according to the procedure of Laemmli (1970) as modified by Ames et al. (1974). Samples were mixed $1: 1$ with sample buffer (containing $4 \%$ SDS, w/v), and boiled for $5 \mathrm{~min} ; 10 \mu \mathrm{l}$ portions were then applied to the gel. LPS bands were detected by the method of Tsai \& Frasch (1982).

Analytical procedures. Total carbohydrate was measured by the phenol procedure (Hanson \& Phillips, 1981) with glucose as standard. 2-keto-3-deoxyoctulosonic acid (KDO) was measured by the thiobarbituric acid method after hydrolysis of samples in $0.05 \mathrm{M}$ sulphuric acid for $30 \mathrm{~min}$ (Karkhanis et al., 1978). Monosaccharides were also analysed to their alditol acetate derivatives by GLC on a $3 \%$ SP-3840 column (Supelco) as previously described (Tomás \& Jofre, 1985).

Inhibition of serum bactericidal activity by complete and fractionated LPS. LPS was suspended in PBS ( $\mathrm{pH} 7.2$ ) to a final concentration of $1-5 \mathrm{mg} \mathrm{ml}^{-1}$ and briefly sonicated at $4{ }^{\circ} \mathrm{C}$ until the solution cleared. LPS solution in the concentration range $0.01-0.2 \mathrm{mg} \mathrm{m}^{-1}$ was added to $0.5 \mathrm{ml}$ serum in a tube. The volume was adjusted to $0.9 \mathrm{ml}$ with PBS, and the solution was incubated at $37^{\circ} \mathrm{C}$ with shaking ( 100 r.p.m.) for 30 $\min$. Then, $0 \cdot 1 \mathrm{ml}$ of an exponential phase culture $\left(5 \times 10^{7} \mathrm{c}\right.$.f.u. $)$ was added to the tube and incubated at $37^{\circ} \mathrm{C}$ for $3 \mathrm{~h}$; samples were taken hourly and bacterial concentrations determined by dilution and plating on agar. Similar experiments were done with LPS fractions which were lyophilized, resuspended in PBS and added to a final concentration of $0.1 \mathrm{mg} \mathrm{ml}^{-1}$ to $0.5 \mathrm{ml}$ serum. Controls without LPS or LPS fractions showed no inhibition of serum bactericidal activity.

Measurement of the anti-complementary activity of LPS. The anticomplementary activity of LPS or LPS fractions was measured

\section{Table 1. Aeromonas hydrophila strains}

Strains AH-3, Ba5 and AH-101 are wild-types. Strains AH-8, AH-51 and AH-151 are spontaneous mutants resistant to bacteriophage 18, while strains $\mathrm{AH}-53, \mathrm{AH}-54$ and $\mathrm{AH}-159$ are spontaneous mutants resistant to bacteriophage PM2. Strains AH-34, AH-301, AH-302, AH-303, AH-304 and AH-305 are isogenic serumresistant mutants obtained from serum-sensitive strains.

\begin{tabular}{|c|c|c|}
\hline Strain & Relevant characteristics & Origin \\
\hline $\mathrm{AH}-3$ & Serotype $O: 34$, serum resistant & Merino et al., 1989 \\
\hline AH-8 & Rough, isogenic mutant derived from $\mathrm{AH}-3$, serum sensitive & Merino et al., $1990 a$ \\
\hline AH-53 & Rough, isogenic mutant derived from $\mathrm{AH}-3$, serum sensitive & Merino et al., $1990 \mathrm{~b}$ \\
\hline AH-34 & Rough, isogenic mutant derived from $\mathrm{AH}-8$, serum resistant & This work \\
\hline AH-301 & Rough, isogenic mutant derived from $\mathrm{AH}-53$, serum resistant & This work \\
\hline $\mathrm{Ba} 5$ & Serotype $0: 34$, serum resistant & Lallier et al., 1984 \\
\hline AH-51 & Rough, isogenic mutant derived from Ba5, serum sensitive & Merino et al., $1990 a$ \\
\hline AH-54 & Rough, isogenic mutant derived from $\mathrm{Ba5}$, serum sensitive & Merino et al., $1990 \mathrm{~b}$ \\
\hline AH-302 & Rough, isogenic mutant derived from $\mathrm{AH}-51$, serum resistant & This work \\
\hline AH-303 & Rough, isogenic mutant derived from $\mathrm{AH}-54$, serum resistant & This work \\
\hline AH-101 & Serotype $0: 34$, serum resistant & Merino et al., 1989 \\
\hline AH-151 & Rough, isogenic mutant derived from $\mathrm{AH}-101$, serum sensitive & Merino et al., $1990 a$ \\
\hline AH-159 & Rough, isogenic mutant derived from $\mathrm{AH}-101$, serum sensitive & Merino et al., $1990 \mathrm{~b}$ \\
\hline AH-304 & Rough, isogenic mutant derived from $\mathrm{AH}-151$, serum resistant & This work \\
\hline AH-305 & Rough, isogenic mutant derived from $\mathrm{AH}-159$, serum resistant & This work \\
\hline
\end{tabular}


according to Shafer et al. (1984), with slight modifications. NHS $(0.1 \mathrm{ml})$ was mixed with LPS $\left(0.01-0.2 \mathrm{mg} \mathrm{ml}^{-1}\right)$ or LPS fractions $\left(0.1 \mathrm{mg} \mathrm{ml}^{-1}\right)$ suspended in PBS, or PBS alone, to a final volume of $0.2 \mathrm{ml}$, and incubated with shaking at $37^{\circ} \mathrm{C}$ for $30 \mathrm{~min}$. Antibodysensitized sheep erythrocytes in $0.2 \mathrm{ml}$ PBS were added to a four-fold dilution of treated NHS and incubated for an additional $30 \mathrm{~min}$ at $37^{\circ} \mathrm{C}$. Ice-cold saline $(3 \mathrm{ml})$ was added to the mixture, the cells were pelleted by centrifugation, and the absorbance of the supernatant was measured at $412 \mathrm{~nm}$. The positive control was sensitized sheep erythrocytes plus NHS without added LPS or LPS fraction, and the negative control was LPS or LPS fraction without added NHS.

Concentration of $\mathrm{Clq}$ and $\mathrm{C} 3$ complement components were also measured using specific antibodies as described by Theofilopoulos $e t$ al. (1980). Briefly, specific anti-Clq or anti-C3 sera (Sigma) were coated onto a microtitre plate overnight at $4{ }^{\circ} \mathrm{C}$, washed and incubated for $1 \mathrm{~h}$ at $37^{\circ} \mathrm{C}$ with $1 \%$ human serum albumin. Meanwhile, NHS was treated with $A$. hydrophila whole cells or purified LPS (complete or fractionated) for $30 \mathrm{~min}$ at $37^{\circ} \mathrm{C}$. Untreated NHS was used as a standard, using the same incubation period. After washing the plates, the treated or untreated NHS was added and incubated for $90 \mathrm{~min}$ at $37^{\circ} \mathrm{C}$. The plates were then washed again and incubated for $1 \mathrm{~h}$ at $37^{\circ} \mathrm{C}$ with protein-A-alkaline-phosphatase conjugate (Sigma). After washing the plates, the colour reaction was developed with 4nitrophenyl phosphate $\left(1 \mathrm{mg} \mathrm{ml}^{-1}\right)$ and the $A_{405}$ recorded.

Binding of C $3 b$ and C5b-9 to A. hydrophila whole cells. The interaction between whole $A$. hydrophila $0: 34$ cells and complement $\mathrm{C} 3 \mathrm{~b}$ and C5b-9 components was quantified using an enzyme immunoassay. Preopsonized bacteria $(10 \mathrm{~min})$ with $90 \%$ NHS were washed twice with cold PBS by microcentrifugation, and were incubated with antiC3b or anti-C5b-9 (Calbiochem) $(1: 100$ in PBS plus $1 \%$ BSA), washed intensively by microcentrifugation, followed by protein-A-alkalinephosphatase incubation at $37^{\circ} \mathrm{C}$ for $45 \mathrm{~min}$ (1:100 in PBS). After washing, the colour reaction was developed as before and the $A_{405}$ recorded.

\section{Results}

\section{Survival in NHS}

Mutants resistant to bacteriophages 18 and PM2 from different $\boldsymbol{A}$. hydrophila strains were described previously (Merino et al., 1990a, b). They were devoid of both Oantigen polysaccharide and part of the LPS-core oligosaccharide. Results of NHS survival experiments at $37^{\circ} \mathrm{C}$ with these mutants and their respective wild-type strains are shown in Table 2, and no important differences were observed in NHS survival experiments at $20^{\circ} \mathrm{C}$. Strains AH-53, AH-54, AH-159, AH-8, AH-51 and $\mathrm{AH}-151$ showed a marked decrease in viability (under $1 \%$ survival) after $2 \mathrm{~h}$. No decrease was observed with wild-type strains $\mathrm{AH}-3, \mathrm{Ba} 5$ or $\mathrm{AH}-101$ or strains AH-34, AH-301, AH-302, AH-303, AH-304 and AH-305 (serum-resistant mutants derived from strains AH-8, $\mathrm{AH}-53$, AH-51, AH-54, AH-151, and AH-159, respectively). These isogenic serum-resistant mutants were still devoid of the O-antigen polysaccharide chains on their LPS, and their LPS-core showed a lower migration rate on SDS-PAGE gels than their isogenic rough serumsensitive strains (Fig. 1). Further, the serum-resistant mutants showed alterations in the chemical composition of their LPS core oligosaccharides versus their isogenic serum-sensitive strains. Table 3 shows the chemical composition of LPS from wild-type strains (0:34),

Table 2. Survival of A. hydrophila strains in NHS and in complement-depleted NHS

Complement depletion was achieved either by heating NHS for $30 \mathrm{~min}$ at $56^{\circ} \mathrm{C}$ or by treating the NHS with $20 \mathrm{~mm}$-EDTA for $1 \mathrm{~h}$ at $37^{\circ} \mathrm{C}$.

\begin{tabular}{|c|c|c|c|c|c|c|}
\hline \multirow[b]{3}{*}{ Strain } & \multicolumn{6}{|c|}{ Percentage of inoculum surviving on: } \\
\hline & \multicolumn{3}{|c|}{ NHS } & \multicolumn{3}{|c|}{ Complement-depleted NHS } \\
\hline & $1 \mathrm{~h}$ & $2 \mathrm{~h}$ & $3 \mathrm{~h}$ & $1 \mathrm{~h}$ & $2 \mathrm{~h}$ & $3 \mathbf{h}$ \\
\hline AH-3 & 96 & 99 & 101 & 102 & 103 & 109 \\
\hline AH-8 & 1.8 & 0.2 & $<0.1$ & 104 & 103 & 112 \\
\hline AH-53 & 0.8 & $<0 \cdot 1$ & $<0 \cdot 1$ & 103 & 105 & 108 \\
\hline AH-34 & 94 & 100 & 103 & 106 & 113 & 120 \\
\hline AH-301 & 95 & 101 & 105 & 102 & 107 & 114 \\
\hline Ba5 & 98 & 102 & 105 & 104 & 107 & 116 \\
\hline AH-51 & 1.9 & $0 \cdot 3$ & $<0.1$ & 100 & 106 & 108 \\
\hline AH-54 & 0.7 & $<0.1$ & $<0.1$ & 102 & 104 & 107 \\
\hline AH-302 & 96 & 100 & 103 & 103 & 109 & 118 \\
\hline AH-303 & 97 & 99 & 102 & 104 & 109 & 117 \\
\hline AH-101 & 97 & 100 & 108 & 102 & 110 & 116 \\
\hline AH-151 & 1.7 & 0.1 & $<0.1$ & 100 & 102 & 104 \\
\hline AH-159 & 0.9 & $<0.1$ & $<0.1$ & 99 & 101 & 105 \\
\hline AH-304 & 98 & 101 & 106 & 103 & 111 & 118 \\
\hline AH-305 & 97 & 102 & 106 & 105 & 112 & 120 \\
\hline
\end{tabular}




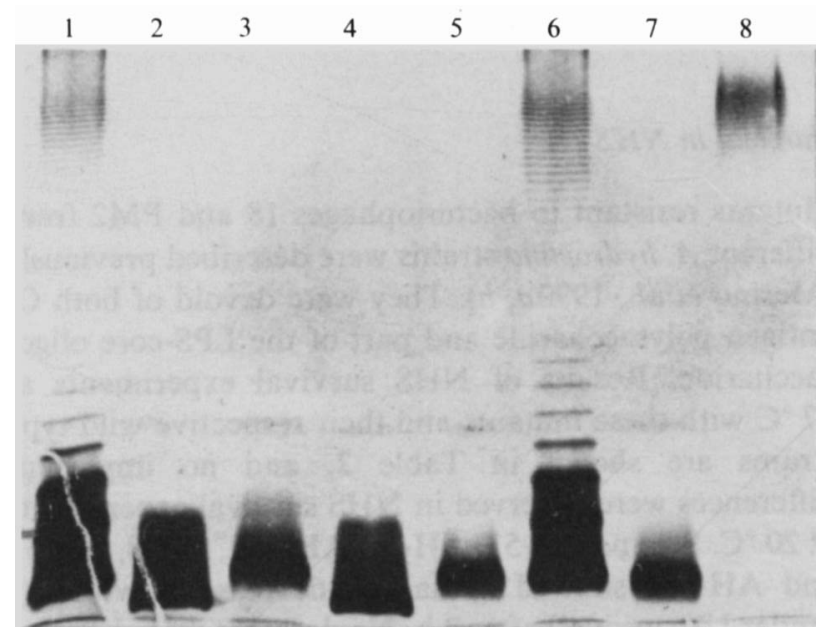

Fig. 1. SDS-PAGE of LPS purified from different $A$. hydrophila $0: 34$ strains, detected according to Tsai \& Frasch (1982). Lanes: 1, LPS from strain AH-3; 2, LPS from strain AH-8; 3, LPS from strain AH-34; 4, LPS from strain AH-53; 5, LPS from strain AH-301; 6, complete LPS from strain AH-3; 7, LMM-LPS from strain AH-3 (pooled fractions); and 8, HMM-LPS from strain AH-3 (pooled fractions).

phage-resistant mutants (serum-sensitive) (Merino et al., $1990 a, b)$ and serum-resistant mutants. The main change observed in the LPS composition of the serum-resistant mutants versus the serum-sensitive phage-resistant mutants is the substitution of glucose for galactose in the LPS core region.

To determine whether differences in survival in NHS among strains were due to nutritional rather than bactericidal factors, we measured survival in serum which was heated or treated with 20 mM-EDTA to destroy complement. These results (Table 2) showed no significant differences between the wild-type strains and the rough isogenic mutants ( $\mathrm{AH}-8, \mathrm{AH}-53, \mathrm{AH}-51, \mathrm{AH}-$ 54, $\mathrm{AH}-151$, and $\mathrm{AH}-159)$.

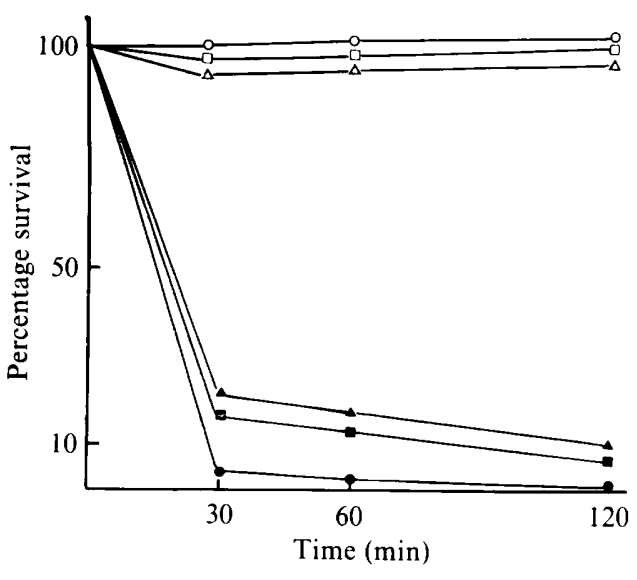

Fig. 2. The bactericidal effects of NHS on the serum-sensitive strain A. hydrophila AH-53. Control serum (O) was unaltered prior to the addition of cells; otherwise serum was pretreated as follows: heated at $56{ }^{\circ} \mathrm{C}$ for $30 \mathrm{~min}(O), 20 \mathrm{~mm}$-EDTA $(\square), 20 \mathrm{~mm}$-EGTA plus $2 \mathrm{~mm}$ $\mathrm{MgCl}_{2}(\triangle), 2 \mathrm{mg} \mathrm{ml}^{-1}$ inulin $(\triangle)$, or heated at $50^{\circ} \mathrm{C}$ for $20 \mathrm{~min}$

\section{Mechanism of complement activation by $A$. hydrophila strains.}

The rough serum-sensitive strain AH-53 was rapidly killed in the presence of NHS (Fig. 2). However, serum treated with EDTA, or heated at $56{ }^{\circ} \mathrm{C}$ for $30 \mathrm{~min}$ (which inhibits both the CCP and ACP), was virtually nonbactericidal. Also, serum treated with $\mathrm{Mg}^{2+}$-EGTA (which selectively inhibits $\mathrm{CCP}$ ), was nonbactericidal, whereas serum pretreated either with inulin or by heating at $50{ }^{\circ} \mathrm{C}$ for $20 \mathrm{~min}$ (which depletes ACP), was strongly bactericidal (Fig. 2). Similar results were obtained with another serum-sensitive strain $\mathrm{AH}-8$. These results suggested that serum killing of sensitive $A$. hydrophila $\mathrm{O}: 34$ strains is mediated by the CCP in the absence of specific antibody.

Table 3. Chemical composition of purified LPS from A. hydrophila strains

\begin{tabular}{|c|c|c|c|c|c|c|c|c|}
\hline \multirow[b]{2}{*}{ Strain } & \multicolumn{8}{|c|}{ Content $\left[\mu \mathrm{mol}(\mathrm{mg} \mathrm{LPS})^{-1}\right]$ of: } \\
\hline & $\mathrm{KDO}^{*}$ & L-Heptose $\dagger$ & D-heptose $†$ & Pentose $†$ & Glucose $†$ & Galactose $†$ & Rhamnose $†$ & Hexosamines $\dagger$ \\
\hline AH-3 & 0.018 & $0 \cdot 31$ & 0 & 0 & 1.57 & 0 & 0 & 0.41 \\
\hline AH-8 & 0.043 & $1 \cdot 12$ & 0 & 0 & 1.48 & 0 & 0 & 0 \\
\hline AH-53 & 0.051 & $1 \cdot 25$ & 0 & 0 & $1 \cdot 32$ & 0 & 0 & 0 \\
\hline AH-34 & 0.041 & 0.98 & 0 & 0 & 0 & 1.96 & 0 & 0 \\
\hline AH-301 & $0 \cdot 048$ & 1.02 & $\mathbf{0}$ & 0 & 0 & 1.80 & 0 & 0 \\
\hline Ba5 & $0 \cdot 019$ & $0 \cdot 31$ & $\mathbf{0}$ & 0 & 1.55 & 0 & 0 & 0.43 \\
\hline AH-51 & 0.042 & $1 \cdot 10$ & 0 & 0 & 1.49 & 0 & 0 & 0 \\
\hline AH-54 & 0.050 & $1 \cdot 26$ & 0 & 0 & $1 \cdot 29$ & 0 & 0 & 0 \\
\hline AH-302 & 0.043 & 1.01 & 0 & 0 & 0 & 1.94 & 0 & 0 \\
\hline AH-303 & 0.046 & 1.06 & 0 & 0 & 0 & 1.84 & 0 & 0 \\
\hline
\end{tabular}

* Assayed by the colorimetric method of Karkhanis et al. (1978).

$\dagger$ Assayed by GLC. 
Table 4. Inhibition of bactericidal activity of serum against serum-sensitive strains of A. hydrophila by homologous and heterologous LPS, and pooled fractions of LPS

The LPS concentration used was $100 \mu \mathrm{g} \mathrm{ml}^{-1}$. Results are means of three independent experiments.

\begin{tabular}{|c|c|c|c|c|c|c|c|}
\hline \multirow[b]{4}{*}{ Strain } & \multicolumn{7}{|c|}{ Percentage survival of bacteria after $180 \mathrm{~min}$ incubation in: } \\
\hline & \multicolumn{5}{|c|}{ NHS plus LPS from the following strains } & \multirow{2}{*}{\multicolumn{2}{|c|}{$\begin{array}{l}\text { NHS plus LPS } \\
\text { fractions }\end{array}$}} \\
\hline & \multirow{2}{*}{$\begin{array}{l}\text { Control } \\
\text { (NHS) }\end{array}$} & \multicolumn{2}{|c|}{ Serum-sensitive } & \multicolumn{2}{|c|}{ Serum-resistant } & & \\
\hline & & $\mathrm{AH}-8$ & AH-53 & $\mathrm{AH}-3$ & AH-34 & HMM-LPS & LMM-LPS \\
\hline AH-8 & $<0 \cdot 1$ & 101 & 103 & 99 & 101 & $0 \cdot 6$ & 98 \\
\hline $\mathrm{AH}-53$ & $<0 \cdot 1$ & 100 & 98 & 98 & 102 & $0 \cdot 7$ & 99 \\
\hline $\mathrm{AH}-51$ & $<0 \cdot 1$ & 104 & 102 & 97 & 104 & $0 \cdot 8$ & 102 \\
\hline AH-54 & $<0 \cdot 1$ & 100 & 103 & 98 & 100 & 0.6 & 96 \\
\hline $\mathrm{AH}-151$ & $<0.1$ & 102 & 100 & 99 & 103 & 0.6 & 98 \\
\hline AH- 159 & $<0.1$ & 103 & 103 & 96 & 101 & 0.9 & 101 \\
\hline
\end{tabular}

Table 5. Concentration of complement components $C 1 q$ and $C 3$ in fresh NHS untreated or treated with whole cells, or LPS fractions, from different $A$. hydrophila $O: 34$ strains

Results are means from experiments done at least twice in triplicate. Standard deviations were all $<0.07$.

\begin{tabular}{|c|c|c|c|c|c|c|c|c|c|}
\hline \multirow[b]{3}{*}{ Component } & \multirow[b]{3}{*}{ Untreated } & \multicolumn{8}{|c|}{$\begin{array}{l}\text { Concentration of } \mathrm{Clq} \text { or } \mathrm{C} 3 \text { in arbitrary units } \\
\left(A_{405} \text { ELISA measurements }\right) \text { in NHS treated with: }\end{array}$} \\
\hline & & \multicolumn{3}{|c|}{ Whole cells } & \multicolumn{3}{|c|}{ Complete LPS } & \multicolumn{2}{|c|}{ LPS fractions } \\
\hline & & $\mathrm{AH}-3$ & AH-8 & AH-34 & $\mathrm{AH}-3$ & $\mathrm{AH}-8$ & AH-34 & HMM $^{*}$ & $\mathrm{LMM}^{*}$ \\
\hline $\mathrm{Clq}$ & $1 \cdot 32$ & $0 \cdot 35$ & $0 \cdot 27$ & $0 \cdot 29$ & 0.41 & $0 \cdot 32$ & $0 \cdot 35$ & $1 \cdot 29$ & $0 \cdot 33$ \\
\hline $\mathrm{C} 3$ & 1.98 & 0.44 & 0.39 & 0.41 & 0.46 & 0.40 & 0.42 & 1.87 & 0.41 \\
\hline
\end{tabular}

* Isolated from strain AH-3.

Inhibition of serum bactericidal activity by $A$. hydrophila $0: 34$ LPS

Various concentrations of purified whole LPS (a mixture of O-antigen-containing and O-antigen-deficient LPS molecules) from $A$. hydrophila AH-3 inhibited the bactericidal activity of NHS in a dose-dependent manner when tested against the sensitive strain AH-53. The survival of AH-53 cells in NHS after $3 \mathrm{~h}$ of incubation at $37{ }^{\circ} \mathrm{C}$ was $0,26,79,98,101$ and $102 \%$ at LPS concentrations of $0,0.025,0.05,0.1,0.2$ and $0.4 \mathrm{mg}$ $\mathrm{ml}^{-1}$, respectively. Purified whole LPS at $0 \cdot 1 \mathrm{mg}-\mathrm{ml}^{-1}$ from serum-resistant (AH-3 and $\mathrm{AH}-34)$ or serumsensitive (AH-8 and AH-53) A. hydrophila strains also inhibited the bactericidal activity of serum when tested against the sensitive strains AH-8, AH-53, AH-51, AH54, AH-151 and AH-159 (Table 4).

\section{Inhibition of bactericidal activity by LPS fractions}

LPS from A. hydrophila AH-3 or Ba5 was fractionated using Sephacryl S-300, and the presence of LPS in column fractions was monitored by determination of $\mathrm{KDO}$ and total hexose, and by SDS-PAGE. Pooled fractions containing HMM-LPS and pooled LMM-LPS are shown in Fig. 1. Serum-sensitive strains of $A$. hydrophila showed a high percentage survival $(>96 \%)$ in NHS treated with pooled LPS fractions having a low hexose:KDP ratio (LMM-LPS), whereas if NHS was pretreated with pooled LPS fractions having a high hexose:KDO ratio (HMM-LPS) the percentage survival of serum-sensitive strains was always less than $1 \%$ (Table 4), although some residual effect on the bactericidal activity remained.

\section{Anticomplementary activity of $A$. hydrophila $0: 34$ LPS}

The complement-absorbing activity of LPS from $\boldsymbol{A}$. hydrophila $\mathrm{AH}-3$ or $\mathrm{Ba} 5$ was measured to determine whether inhibition of serum bactericidal activity was due to depletion of serum complement. The complementabsorbing activity of LPS from $A$. hydrophila AH-3 and the serum-sensitive strains AH-53 and AH-54 was dosedependent (Fig. 3). Furthermore, concentrations of 


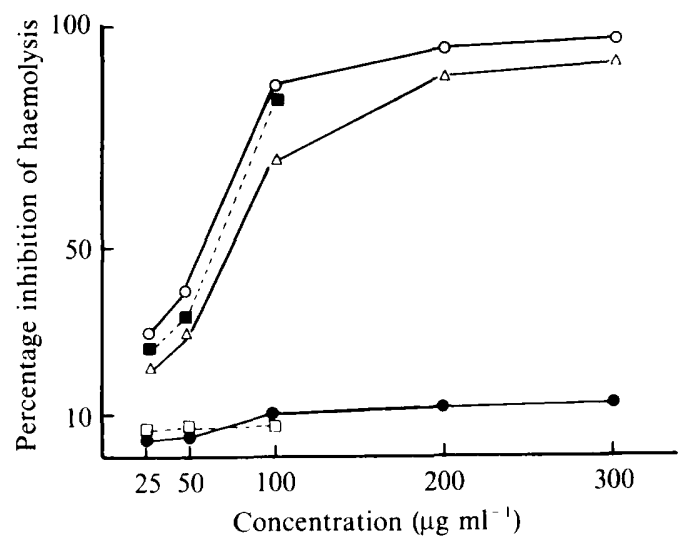

Fig. 3. Inhibition of complement-mediated haemolysis of sensitized sheep erythrocytes. Erythrocytes were incubated for $30 \mathrm{~min}$ in NHS as control, or with NHS containing whole LPS from $A$. hydrophila AH-3 $(\triangle)$ or AH-53 (O), LMM-LPS from strain AH-3 (ם), or HMM-LPS from the same strain $(\square)$ or HMM-LPS from strain Ba5 (O).

Table 6. Interaction of complement components $C 3 b$ and $C 5 b-9$ with $A$. hydrophila $O: 34$ whole cells, measured as $A_{405}$ in an ELISA assay

Results are means from experiments done at least twice in triplicate.

\begin{tabular}{lcc}
\hline \hline & \multicolumn{2}{c}{$\begin{array}{c}\text { Relative concentration } \\
\left.A_{405} \text { ELISA values }\right)\end{array}$} \\
\cline { 2 - 3 } Strain & $\mathrm{C} 3 \mathrm{~b}$ & $\mathrm{C} 5 \mathrm{~b}-9$ \\
\hline $\mathrm{AH}-3$ & $0.32 \pm 0.06$ & $0.08 \pm 0.03$ \\
$\mathrm{AH}-8$ & $1.52 \pm 0.13$ & $1.32 \pm 0.15$ \\
$\mathrm{AH}-53$ & $1.63 \pm 0.14$ & $1.36 \pm 0.13$ \\
$\mathrm{AH}-34$ & $0.09 \pm 0.04$ & $0.09 \pm 0.02$ \\
$\mathrm{AH}-301$ & $0.10 \pm 0.04$ & $0.07 \pm 0.03$ \\
Ba5 & $0.30 \pm 0.07$ & $0.07 \pm 0.03$ \\
$\mathrm{AH}-51$ & $1.54 \pm 0.15$ & $1.42 \pm 0.14$ \\
$\mathrm{AH}-54$ & $1.60 \pm 0.12$ & $1.45 \pm 0.15$ \\
$\mathrm{AH}-302$ & $0.08 \pm 0.03$ & $0.09 \pm 0.02$ \\
$\mathrm{AH}-303$ & $0.09 \pm 0.04$ & $0.07 \pm 0.01$ \\
\hline \hline
\end{tabular}

complement components $\mathrm{Clq}$ and $\mathrm{C} 3$ were depleted when NHS was treated with whole cells or complete LPS from $A$. hydrophila serum-sensitive or serum-resistant strains, as well as LMM-LPS (but not HMM-LPS) from strain AH-3 (Table 5).

\section{Binding of $C 3 b$ and $C 5 b-9$ to A. hydrophila $O: 34$ whole} cells

As shown in Table 6, serum-resistant strains of $A$. hydrophila $\mathrm{O}: 34$ did not bind $\mathrm{C} 3 \mathrm{~b}$ or $\mathrm{C} 5 \mathrm{~b}-9$, whereas the serum-sensitive strains interacted strongly with $\mathrm{C} 3 \mathrm{~b}$ or C5b-9, producing $A_{405}$ values in ELISA which were all $>1 \cdot 31$.

\section{Discussion}

The bactericidal effects of immune or nonimmune sera are mediated by activated components of the CCP and ACP (Pangburn, 1983; Rowley, 1968; Taylor, 1983, 1988). Activation of either pathway can lead to membrane damage, usually resulting in cell death. Our study of complement activation by $A$. hydrophila $\mathrm{O}: 34$ strains indicates that only the CCP was involved in serum killing of sensitive strains. Selective inhibition of the CCP by treatment with $\mathrm{Mg}^{2+}$-EGTA abolished serum bactericidal activity, and serum treated with inulin, or heated at $50{ }^{\circ} \mathrm{C}$ for $20 \mathrm{~min}$, was still bactericidal. Thus the ACP is probably not involved in serum-killing of sensitive strains of $A$. hydrophila $0: 34$. Other Gramnegative bacteria such as Neisseria gonorrhoeae (Schafer et al., 1984), Pseudomonas aeruginosa (Schiller et al., 1984), and Haemophilus ducreyi (Odumeru et al., 1985), have also been shown to activate only the CCP; however, other bacteria, such as Haemophilus influenzae (Quinn et al., 1977), Salmonella spp. (Tomás et al., 1988), Escherichia coli (Tomás et al., 1988), and Klebsiella pneumoniae (Ciurana \& Tomás, 1987), activate both pathways.

The susceptibility of many Gram-negative bacteria to the bactericidal activity of immune and non-immune sera has often been attributed to their LPS composition. LPS from serum-resistant and serum-sensitive strains of A. hydrophila $0: 34$ inhibited the serum bactericidal activity against sensitive strains, and activated complement, as measured either by the inhibition of haemolysis with sensitized sheep erythrocytes, or by direct measurement of components $\mathrm{Clq}$ and $\mathrm{C} 3$ in treated serum.

Only the low-molecular-mass fractions of $A$. hydrophila O:34 LPS inactivated serum bactericidal activity, prevented haemolysis of sensitized sheep erythrocytes, and depleted the levels of $\mathrm{Clq}$ and $\mathrm{C} 3$ complement components from NHS after $30 \mathrm{~min}$ incubation at $37^{\circ} \mathrm{C}$; this indicates a relationship between blocking of serum bactericidal activity and complement-absorbing activity of these LPS fractions. On the other hand, A. hydrophila $\mathrm{O}: 34$ LPS fractions containing HMM-LPS, i.e. only Oantigen-containing LPS molecules, neither inactivated the serum bactericidal reaction, nor inhibited the haemolysis of sensitized sheep erythrocytes, nor depleted $\mathrm{Clq}$ or $\mathrm{C} 3$ complement components in treated NHS.

Serum-sensitive strains of Gram-negative bacteria may activate the CCP, leading to the formation of $\mathrm{C} 5 \mathrm{~b}-9$ complexes which cause membrane damage and cell death (Taylor, 1988). For this reason, the serum-sensitive strains are rapidly killed by NHS. However the wild-type strains (serum-resistant) also activated the $\mathrm{CCP}$, but showed only minor binding of $\mathrm{C} 3 \mathrm{~b}$ and no formation of C5b-9 complexes. This may be due to binding of C3b by O-antigen (HMM-LPS) sufficiently far away from the 
membrane to exclude the formation of $\mathrm{C} 5 \mathrm{~b}-9$ complexes, so that the cells are still resistant to NHS. Although purified LPS abolishes the bacterial activity of sera when fresh bacteria are subsequently added, it does not necessarily follow that LPS inhibits the bacterium :complement interaction in vivo.

Finally, the isogenic serum-resistant mutants (rough strains) derived from serum-sensitive strains activated the $\mathrm{CCP}$, but no $\mathrm{C} 3 \mathrm{~b}$ binding was observed under our experimental conditions. In these mutants there is a substitution of glucose for galactose in the LPS core oligosaccharides, a change that also influences the electrophoretic mobility of the LPS. At present we can not explain how changes in the LPS core oligosaccharides can prevent $\mathrm{C} 3 \mathrm{~b}$ binding, but without binding of $\mathrm{C} 3 \mathrm{~b}$ to whole cells there is no formation of C5b-9 complexes.

This study has more closely defined the role of LPS, and specially the core oligosaccharides from the LPS core, in the resistance of $\boldsymbol{A}$. hydrophila $\mathrm{O}: 34$ strains to serum-killing of these strains.

Part of this research has been supported by a grant from CIRIT (Generalitat de Catalunya).

\section{References}

Ames, B. N. \& Dubin, D. T. (1960). The role of polyamines in the neutralization of bacteriophage deoxyribonucleic acid. Journal of Biological Chemistry 255, 769-775.

CiUrana, B. \& Tomás, J. M. (1987). Role of lipopolysaccharide and complement susceptibility of Klebsiella pneumoniae to non-immune serum. Infection and Immunity 55, 2741-2746.

Dooley, J. S. G., Lallier, R., Shaw, D. H. \& Trust, T. J. (1985). Electrophoretic and immunochemical analyses of the lipopolysaccharides from various strains of Aeromonas hydrophila. Journal of Bacteriology 164, 263-269.

EIDINGER, D., BELLO, E. \& MATES, A. (1977). The heterocytotoxicity of human serum. I. Activation of the alternative complement pathway by heterologous target cells. Cell Immunology 29, 1-186.

Fine, D. P., Marney, S. R., Colley, D. G., Sergent, J. S. \& Desprez, R. M. (1972). C3 shunt activation in human serum chelated with EGTA. Journal of Immunology 109, 807-809.

FreIJ, B. J. (1984). Aeromonas: biology of the organism and diseases in children. Pediatric Infectious Diseases 3, 164-175.

GLYNN, A. A. \& HowaRD, C. J. (1970). The sensitivity to complement of strains of Escherichia coli related to their $\mathrm{K}$ antigens. Immunology 18, 331-346.

Gotze, O. \& Muller-Eberhard, H. J. (1971). The C3 activator system: and alternative pathway of complement activation. Journal of Experimental Medicine 134 (Suppl.), 90-108.

Guyman, L. F., LeE, T. J., Wlastad, D., Schmoyer, A. \& Sparling, P. F. (1978). Altered outer membrane components in serum-sensitive and serum-resistant strains of Neisseria gonorrhoeae. In Immunology of Neisseria gonorrhoeae, pp. 139-141, Edited by G. F. Brooks, E. C. Gotschlich, K. K. Holmes, W. D. Sawyer \& F. E. Young. Washington, DC: American Society of Microbiology.

Hanson, R. S. \& Phillips, J. A. (1981). Chemical composition. In Manual of Methods for General Bacteriology, pp. 328-364, Edited by P. Gerhardt, R. G. E. Murray, R. N. Costilow, E. W. Nester, W. A. Wood, N. R. Krieg \& G. B. Phillips. Washington, DC: American Society of Microbiology.
Hildebrant, J. F., Mayer, L. W., Wang, S. P. \& Buchanan, T. M. (1978). Neisseria gonorrhoeae acquire a new principal outer membrane protein when transformed to resistance to serum. Infection and Immunity 20, 267-273.

Howard, S. P. \& Buckley, J. T. (1985). Phospholipids and lipopolysaccharide of Aeromonas hydrophila. Journal of Bacteriology 161, 463-465.

JANDA, J. M., ClaRK, R. B. \& BRENDEN, R. (1985). Virulence of Aeromonas species as assessed through mouse lethality. Current Microbiology 12, 163-168.

Karkhanis, Y. D., Zeltner, J. Y., Jackson, J. J. \& Carlo, D. J. (1978). A new and improved microassay to determine 2-keto-3deoxyoctonate in lipopolysaccharide of Gram-negative bacteria. Analytical Biochemistry 85, 595-601.

LAEMMLI, U. K. (1970). Cleavage of structural proteins during assembly of the head of bacteriophage T4. Nature, London 227, 595601 .

Lallier, R., Bernard, F. \& Lalonde, G. (1984). Difference in the extracellular products of two strains of Aeromonas hydrophila virulent and weakly virulent for fish. Canadian Journal of Microbiology 30 , 900-904.

LJUNGH. A. \& WADSTROM, T. (1983). Toxins of Vibrio parahaemolyticus and Aeromonas hydrophila. Journal of Toxicology, Toxin Reviews 1, 257-307.

Merino, S. \& Thomas, J. M. (1988). Characterization of an Aeromonas hydrophila strain isolated on a septicemic out-break in a fish farm on Spain. Microbiologia 4, 181-184.

MERINo, S., BENEDI, V. J. \& Tomás, J. M. (1989). Aeromonas hydrophila strains with moderate virulence. Microbios 59, 165-173.

MERINo, S., CAMPRUBI, S. \& Tomás, J. M. (1990a). Identification of the cell surface receptor for bacteriophage 18 from Aeromonas hydrophila. Research in Microbiology 141, 173-180.

MERINo, S., CAMprubi, S. \& Tomás, J. M. (1990b). Isolation and characterization of bacteriophage PM2 from Aeromonas hydrophila. FEMS Microbiology Letters 68, 239-244.

Moll, A., Manning, P. A. \& Timmis, K. N. (1980). Plasmiddetermined resistance to serum bactericidal activity: a major outer membrane protein, the $t r a T$ gene product, is responsible for plasmidspecified serum resistance in Escherichia coli. Infection and Immunity 28, 359-367.

MoRRISON, D. C. \& KLINE, L. F. (1977). Activation of the classical and properdin-pathways of complement by bacterial lipopolysaccharides. Journal of Immunology 118, 362-368.

MunN, C. B., Ishiguro, E. E., KaY, W. W. \& Trust, T. J. (1982). Role of surface components in serum resistance of virulent Aeromonas salmonicida. Infection and Immunity 36, 1069-1075.

MUSHEL, L. H. \& LARSEN, L. J. (1970). The sensitivity of smooth and rough Gram-negative bacteria to the immune bactericidal reaction. Proceedings of the Society for Experimental Biology and Medicine 133, 345-348.

Nelson, B. W. \& RoANTREe, R. J. (1967). Analyses of lipopolysaccharides extracted from penicillin-resistant, serum-sensitive Salmonella mutants. Journal of General Microbiology 48, 179-188.

Odumeru, J. A., Wiseman, G. M. \& Ronald, A. R. (1985). Role of lipopolysaccharide and complement in susceptibility of Haemophilus ducreyi to human serum. Infection and Immunity 50, 495-499.

OsBorn, M. J. (1966). Preparation of lipopolysaccharide from mutant strains of Salmonella. Methods in Enzymology 8, 161-164.

PANGBURN, M. K. (1983). Activation of complement via the alternative pathway. Federation Proceedings 42, 139-143.

Quinn, P. H., Crosson, F. J., Winkelsrein, J. A. \& Moxon, E. R. (1977). Activation of the alternative complement pathway by Haemophilus influenzae type b. Infection and Immunity 16, 400402.

RICE, P. A. \& KASPER, D. L. (1977). Characterization of gonococcal antigens responsible for induction of bactericidal antibody in disseminated infection: the role of gonococcal endotoxins. Journal of Clinical Investigation 39, 72-81.

Roantree, R. J. \& Pappas, N. C. (1960). The survival of strains of enteric bacilli in the blood stream as related to their sensitivity to the bactericidal effect of serum. Journal of Clinical Investigation 39, 8288. 
Rowley, D. (1968). Sensitivity of rough Gram-negative bacteria to the bactericidal action of serum. Journal of Bacteriology 95, 16471650.

Schiller, N. L., Alazard, M. J. \& Borowski, R. S. (1984). Serum sensitivity of a Pseudomonas aeruginosa mucoid strain. Infection and Immunity 45, 748-755.

Shafer, W. M., Joinier, K., Guyman, L. F., Cohen, M. S. \& SPARLING, P. F. (1984). Serum sensitivity of Neisseria gonorrhoeae: the role of lipopolysaccharide. Journal of Infectious Diseases 149, 175183.

Sutton, A., SChneerson, R., Kendall-Morris, S. \& RobBins, J. B. (1982). Differential complement resistance mediates virulence of Haemophilus influenzae type b. Infection and Immunity 35, 95-104.

TAYLOR, P. W. (1983). Bactericidal and bacteriolytic activity of serum against Gram-negative bacteria. Microbiological Reviews 47, 46-83.

TAYLOR, P. W. (1988). Bacterial resistance to complement. In Virulence Mechanisms of Bacterial Pathogens, pp. 107-120, Edited by J. A. Roth. Washington, DC: American Society of Microbiology.

Theofilopoulos, A. N., Pereira, A. B., Eisenberg, R. A. \& Dixon, F. J. (1980). Assays for detection of complement fixing immune complexes. In Manual of Clinical Immunology, pp. 186-193, edited by N. R. Rose \& H. Friedman. Washington, DC: American Society of Microbiology.
Thomas, L. V., Gross, R. J., Cheasty, T. \& Rowe, B. (1990). Extended serogrouping scheme for motile mesophilic Aeromonas species. Journal of Clinical Microbiology 28, 980-984.

TOMÁs, J. M. \& JoFre, J. (1985). A lipopolysaccharide-specific bacteriophage for $K$. pneumoniae C3. Journal of Bacteriology 162, 1276-1279.

Tomás, J. M., Benedi, V. J., Ciurana, B. \& Jofre, J. (1986). Role of capsule and $O$ antigen in resistance of Klebsiella pneumoniae to serum bactericidal activity. Infection and Immunity 54, 85-89.

Tomás, J. M., Ciurana, B., Benedi, V. J. \& Juarez, A. (1988). Role of lipopolysaccharide and complement susceptibility of Escherichia coli and Salmonella typhimurium to non-immune serum. Journal of General Microbiology 134, 1009-1016.

TsaI, C. M. \& FrasCh, C. E. (1982). A sensitive silver stain for detecting lipopolysaccharide in polyacrylamide gels. Analytical Biochemistry 119, 115-119.

VUKAJLOVICH, S. W. (1986). Antibody-independent activation of the classical pathway of human serum complement by lipid $\mathrm{A}$ is restricted to Re-chemotype lipopolysaccharide and purified lipid A. Infection and Immunity 53, 480-485.

WESTPHAL, O. \& JANN, K. (1965). Bacterial lipopolysaccharides: extraction with phenol-water, and further applications of the procedure. Methods in Carbohydrate Chemistry 5, 83-91. 